Research Article

\title{
An analysis of prescription pattern and adverse drug reaction profile in children treated with antiepileptic drugs in a tertiary care teaching hospital
}

\author{
Meenakshi B. ${ }^{1}$, Ezhil Ramya J. ${ }^{1}$, Ananthy Shri T. R. R. ${ }^{2}$
}

\begin{abstract}
${ }^{1}$ Department of Pharmacology, Tirunelveli Medical College, Tirunelveli, Tamilnadu, India, ${ }^{2}$ Department of Paediatrics, Tirunelveli Medical College Hospital, Tirunelveli, Tamilnadu, India
\end{abstract}

Received: 30 December 2015

Revised: 03 January 2016 Accepted: 03 February 2016

*Correspondence to:

Dr. Meenakshi B.,

Email: meenakshi_b@

tvmc.ac.in

Copyright: (C) the author(s), publisher and licensee Medip Academy. This is an openaccess article distributed under the terms of the Creative Commons Attribution NonCommercial License, which permits unrestricted noncommercial use, distribution, and reproduction in any medium, provided the original work is properly cited.

\begin{abstract}
Background: Epilepsy is a clinical diagnosis made after a child has had two (or) more unprovoked seizures. Ideal goal in the management of childhood epilepsy is complete control with minimal side effects. The incidence of adverse effects is an important issue with antiepileptic drugs (AEDs). We took up this study to analyse the pattern of AEDs prescribed and adverse drug reaction (ADR) profile in children with epilepsy being treated at a tertiary care Teaching hospital of South Tamil Nadu.

Methods: Children of both sexes, 1 to 12 years of age and on AEDs for at least 3 months were included for the study. Patients with febrile seizures, status epilepticus, seizures associated with paralytic stroke, head injury and cerebral palsy were excluded. Demographic data, treatment history and adverse drug events were recorded. Serum liver function tests, complete blood count and peripheral smear and causality analysis of ADRs were done.

Results: Out of 203 patients $122(60.1 \%)$ were males. Average number of AED prescribed per patient was 1.37 . About $68 \%$ received monotherapy. $26.6 \%$ required two drugs and 5.4\% patients required triple drugs. Out of 75 ADRs reported 3 are probable and 72 are possible reactions. The prevalence of ADRs $\left(\mathrm{p}=0.014^{*}\right)$ and anorexia $\left(\mathrm{p}=0.0004^{*}\right)$ were more in patients on polytherapy.

Conclusions: ADRs were more common in patients with combination therapy which insists the need for a newer AED with less toxicity especially for paediatric patients.
\end{abstract}

Keywords: Epilepsy, Antiepileptic drugs, Adverse drug reactions, Prescription pattern

\section{INTRODUCTION}

Epilepsy is a clinical diagnosis made after a child has had two (or) more unprovoked seizures. ${ }^{1}$ It is defined as the sudden, paroxysmal electrical discharge from central nervous system resulting in involuntary motor, sensory and autonomic disturbances with (or) without alterations in sensorium. About $5 \%$ of children are at risk of experiencing a seizure, half of them encounter their first seizure in infancy. ${ }^{2}$ Incidence in first year of life is 120 per1,00,000 and incidence in children between 1 to 10 years is 40 to50 per $1,00,000{ }^{1}$ Children with epilepsy have high rates of behavioural and cognitive problems. Childhood epilepsy may have a lifelong serious effect on social function, an effect that is greater than some other chronic disorders of childhood. ${ }^{1}$ Ideal goal in the management of childhood epilepsy is complete control; if not attainable, a reduction in frequency with minimal side effects. $^{2}$ The incidence of adverse effects is an important issue when prescribing antiepileptic drugs (AEDs), as some of the most effective medications for seizures are associated with a considerable degree of toxicity. Studies indicate that drug tolerability is a significant limiting factor in treatment maintenance, and drug retention rates 
are often determined by side-effect profiles. ${ }^{3}$ The antiepileptic drugs used currently frequently cause unwanted effects that range in severity from minimal impairement of central nervous system to death from aplastic anemia or hepatic failure. ${ }^{4}$ Approximately one third of patients with epilepsy do not respond to treatment with a single anti-epileptic drug and it becomes necessary to try a combination of drugs to control seizures. ${ }^{5}$

Tirunelveli Medical College hospital is a tertiary care teaching hospital. Here paediatric epilepsy clinic is conducted once every week and children with epilepsy under 12 years are being treated. They attend the clinic and get medicines once in 2 weeks. We took up this study to analyse the pattern of antiepileptic drugs prescribed and adverse drug reaction profile in these patients.

\section{Objectives}

- To analyze the prescription pattern in children with epilepsy

- To analyze the adverse drug reactions profile and causality analysis of antiepileptic drugs in pediatric epileptic patients

\section{METHODS}

\section{Study design}

Observational study

\section{Study population}

Paediatric epileptic patients

\section{Inclusion criteria}

Children of both sexes in the age group of 1 year to 12 years who were attending Paediatric epilepsy clinic and on antiepileptic drug at least for 3 months were included for the study.

\section{Exclusion criteria}

Patients with febrile seizures, status epilepticus, seizures associated with acute conditions like paralytic stroke, head injury and cerebral palsy were excluded.

\section{Study duration}

April 2014-May 2014

\section{Methodology}

After getting approval from the Institutional Ethical Committee the study was commenced. Written informed consent was obtained from the parent or care takers. Demographic data and history of illness were recorded. The treatment history was obtained from the diary. Questions related to adverse drug reactions were asked to the parent/care taker and the replies were recorded. All the complaints were recorded as adverse events and if they had a causal association with the drug they were marked as adverse drug reactions. Liver function tests, complete blood count and peripheral smear were done. If the drug was stopped or changed due to ADR the patient was followed up during the next visit after 15 days. If the ADR subsided after withdrawal of the drug it was noted as positive de challenge. For the suspected adverse drug reactions causality analysis was done using WHO causality analysis scale. ${ }^{6}$

\section{RESULTS}

The study was conducted in the outpatient department of paediatric epilepsy clinic. Out of 203 patients studied 122 $(60.1 \%)$ were males and 81(39.9\%) were females (Table 1). Average number of antiepileptic drugs prescribed per patient was 1.37.Among 203 patients $138(68 \%)$ received single antiepileptic drug, 54 (26.6\%) were on two AEDs and $11(5.4 \%)$ patients were on triple drugs (Table 2, $3 \&$ 4). Totally 131 adverse events were reported and only 75 had causal association with the drugs which are mentioned as adverse drug reactions. Out of 75 ADRs 3 are probable reactions and 72 are possible reactions (Table 5). Anorexia, abdominal pain, dizziness, somnolence, sedation, insomnia, cognition impairment, nausea, vomiting anemia, prominent eosinophilia and elevated liver enzymes were the adverse drug reactions noted (Table 6). Totally 39 ADRs were noted in patients on monotherapy and 36 ADRs were reported in patients on more than one drug. Anorexia was significantly more common in patients who were on polytherapy than with monotherapy $\left(\mathrm{p}=0.0004^{*}\right)$. There was no significant difference between monotherapy and combination therapy as far as other ADRs are individually concerned. But overall there is a significant increase in adverse drug reactions with polytherapy than with monotherapy $\left(\mathrm{p}=0.014^{*}\right)$.

I. Patient indicators

II. Average number of drugs prescribed to each patient

Average number of drugs prescribed to each patient $=$

Total number AEDs prescribed to all patients included in the study Total number of patients

$=279 \% 203=1.37$

III. Prescribing Pattern

Table 1: Patient indicators.

\begin{tabular}{|lcl|}
\hline Sex & No. of patients & $\%$ \\
\hline Males & 122 & 60.1 \\
\hline Females & 81 & 39.9 \\
\hline
\end{tabular}


Table 2: Monotherapy.

\begin{tabular}{|lll|}
\hline Drugs & No. of patients & Percentage \\
\hline Sodium valproate & 83 & 40.9 \\
\hline Carbamazepine & 23 & 11.3 \\
\hline Phenobarbitone & 19 & 9.4 \\
\hline Phenytoin & 13 & 6.4 \\
\hline Total & 138 & 68.0 \\
\hline
\end{tabular}

Table 3: Dual drug therapy.

\begin{tabular}{|lll|}
\hline Drugs & No. of patients & Percentage \\
\hline SVP+CBZ & 13 & 6.4 \\
\hline SVP+PBT & 12 & 5.9 \\
\hline SVP+Phenytoin & 7 & 3.4 \\
\hline SVP+Clobazepam & 6 & 3.0 \\
\hline SVP+Clonazepam & 1 & 0.5 \\
\hline SVP+Diazepam & 1 & 0.5 \\
\hline CBZ+PBT & 4 & 1.97 \\
\hline CBZ+Phenytoin & 2 & 0.99 \\
\hline CBZ+Clobazepam & 2 & 0.99 \\
\hline CBZ+ Clonazepam & 2 & 0.99 \\
\hline Phenytoin+PBT & 2 & 0.99 \\
\hline Phenytoin+Diazepam & 1 & 0.49 \\
\hline PBT+Clonazepam & 1 & 0.49 \\
\hline Total & 54 & 26.6 \\
\hline
\end{tabular}

Table 4: Triple drug therapy.

\begin{tabular}{|lll|}
\hline DRUGS & No. of patients & Percentage \\
\hline SVP+CBZ+PBT & 4 & 1.97 \\
\hline SVP+CBZ+Phenytoin & 1 & 0.49 \\
\hline SVP+CBZ+Diazepam & 1 & 0.49 \\
\hline Total & 11 & 5.4 \\
\hline
\end{tabular}

Table 5: Adverse events, adverse drug reactions and causality analysis.

\begin{tabular}{|lll|l|}
\hline $\begin{array}{l}\text { Adverse } \\
\text { events } \\
\text { reported }\end{array}$ & $\begin{array}{l}\text { Adverse } \\
\text { drug } \\
\text { reactions }\end{array}$ & Probable & Possible \\
\hline 131 & $75(36.9 \%)$ & 3 & 72 \\
\hline
\end{tabular}

\section{DISCUSSION}

This study was conducted in the paediatric epilepsy clinic in a tertiary care teaching hospital of south Tamil Nadu. Totally of 203 epileptic children of both sexes were included for the study. Male children $(60.1 \%)$ were more in the study population.

Average number of AEDs per patient was 1.37 which is more or less similar to the other studies conducted in Mumbai, Kashmir and other parts of the world. ${ }^{7-10}$

According to the standard guidelines single drug therapy is preferred. For patients hard to control seizures, multiple drugs are utilized simultaneously. ${ }^{11}$ Among the study subjects approximately two thirds of the children with epilepsy (68\%) were on monotherapy. Sodium valproate was the most commonly used monotherapeutic agent followed by carbamazepine, phenobarbitone and lastly phenytoin. Sodium valproate is useful in many types of seizure disorders like generalized tonic clonic seizures and if both types exist in a single individual also it could be controlled with a single medication with sodium valproate. ${ }^{12}$ This may be the reason for the predominant use of sodium valproate as a monotherapeutic agent. The second most common drug used as monotherapy was carbamazepine. Usually carbamazepine has less adverse reactions and favourable pharmacokinetic profile and lack of cosmetic side effects when compared to phenytoin. ${ }^{12}$ According to standard text books approximately one third of the patients with epilepsy do not respond to treatment with a single antiepileptic drug and combination of drugs is tried to control seizures. There are currently no clear guidelines for rational polytherapy although in theory a combination of drugs with different mechanisms of action may be useful. 5

Table 6: Profile of adverse drug reactions.

\begin{tabular}{|llll|}
\hline ADR & $\begin{array}{l}\text { Patients on } \\
\text { monotherapy } \\
\text { N=138 }\end{array}$ & $\begin{array}{l}\text { Patients on } \\
\text { polytherapy } \\
\text { N=65 }\end{array}$ & P value \\
\hline $\begin{array}{l}\text { Elevated liver } \\
\text { enzymes }\end{array}$ & 10 & 6 & 0.654 \\
\hline Anorexia & 3 & 11 & $0.0004^{*}$ \\
\hline $\begin{array}{l}\text { Abdominal } \\
\text { pain }\end{array}$ & 7 & 7 & 0.166 \\
\hline Dizziness & 2 & 4 & 0.075 \\
\hline Somnolence & 0 & 1 & 0.147 \\
\hline Insomnia & 4 & 3 & 0.547 \\
\hline $\begin{array}{l}\text { Cognition } \\
\text { impairment }\end{array}$ & 0 & 1 & 0.147 \\
\hline $\begin{array}{l}\text { Nausea \& } \\
\text { vomiting }\end{array}$ & 2 & - & 0.332 \\
\hline Sedation & 2 & 1 & 0.964 \\
\hline Anemia & 8 & 2 & 0.424 \\
\hline $\begin{array}{l}\text { Prominent } \\
\text { eosinophilia }\end{array}$ & 1 & - & 0.493 \\
\hline Total & 39 & 36 & $0.014^{*}$ \\
\hline
\end{tabular}

According to the current study $26.6 \%$ of patients were on dual drug therapy and the most commonly prescribed combination was sodium valproate with carbamazepine followed by sodium valproate with phenobarbitone. Out of 203 patients only $11(5.4 \%)$ patients were on triple drug combination and the most commonly used combination was Sodium valproate with phenytoin and carbamazepine.

Totally 131 adverse events were reported and only 75 (36.9\%) had causal association with the drug. Asymptomatic elevation of transaminase was the most commonly noted ADR. Liver enzyme elevation is 
common with carbamazepine and sodium valproate. Asymptomatic elevation of liver enzymes in general do not mandate discontinuation of therapy if not in excess of 2-3 times normal values. ${ }^{13}$ One patient who was on polytherapy and one patient on monotherapy with sodium valproate had elevated liver enzymes more than 2 times the normal and the regimens were changed by the treating paediatrician. After 2 weeks the serum liver enzymes were assessed which came to normal level. There was no significant difference in elevation of liver enzymes between monotherapy and combination therapy.

Other adverse drug reactions reported were anorexia, abdominal pain, dizziness, somnolence, insomnia, cognition impairment, nausea, vomiting, sedation and anemia. Prominent eosinophilia was reported in a patient who was on phenytoin. The regimen was changed by the treating paediatrician. Gastro intestinal toxicity including anorexia, gastric irritability, nausea and vomiting are common with sodium valproate and carbamazepine. ${ }^{1}$ Sedation and dizziness are commonly associated with the use of antiepileptic drugs. Cognition impairment was noted in a patient who was on triple drug therapy. This may either be due to the seizure disorder or to drugs.

Out of 10 cases reported with anemia 8 were on monotherapy and two patients were taking more than one AED. Iron deficiency was noted in 6 children. Although carbamazepine is known to cause anemia, nutritional anemia is more common in India. According to National Family Health Survey (NFHS-3), a household survey in the year 2005-2006 the prevalence of anemia was 70\% in children aged 6-59 months, 55\% in females aged 15-49 years, and $24 \%$ in males aged 15-49 years. ${ }^{14}$ Because hematologic toxicity from carbamazepine occurs early in therapy, complete blood count can be obtained before initiating therapy and at monthly intervals during the first 2 to 3 months of therapy thereafter a yearly and every other year $\mathrm{CBC}$ estimation is sufficient. ${ }^{12}$

Out of 75 ADRs reported, as de challenge was done only in 3 cases and reactions got subsided after changing the drugs, they are probably due to the drugs. All the other 72 ADRs are only possible reactions. No serious adverse reaction was noted during the study period in the study population. No acute cutaneous reaction was reported during the study period.

\section{CONCLUSION}

Out of 203 children who were on antiepileptic medication only $68 \%$ responded to monotherapy while others required combination therapy. Adverse drug reactions were more common in patients who were on combination therapy which insists the need for a newer antiepileptic drugs with less adverse drug reaction profile especially for pediatric patients.

\section{ACKNOWLEDGEMENTS}

We sincerely thank the Department of Pediatrics for their cooperation to conduct the study.

Funding: No funding sources

Conflict of interest: None declared

Ethical approval: The study was approved by the Institutional Ethics Committee

\section{REFERENCES}

1. Bansode A, Zad V, Sawant S, Dudhal K. Awareness about Pharmacovigilance among Resident Doctors in a Tertiary Care Hospital. Journal of Evolution of Medical and Dental Sciences. 2015;4(2):207-10.

2. Camfield PR, Camfield CS. Pediatric Epilepsy: An Overview. In: Kenneth F. Swaiman, Stephen Ashwal, Donna M. Ferriero eds. Paediatric Neurology Principles and Practice. 4th ed. Mosby Elsevier. 2006:981-1005.

3. Kalra V. Seizure Disorders in Children. In: IAP Textbook of Pediatrics. 3rd ed. 2006:322-28.

4. Bootsma HP, Ricker L, Diepman L. Long-term effects of levetiracetam and topiramate in clinical practice: A head-to-head comparison. Seizure. 2008;01:79-93.

5. Mc Namara JO. Pharmacotherapy of epilepsies. In: Laurence Brunton, Bruce Chabner, Bjorn Knollman.eds. Goodman \& Gilman's The Pharmacologic basis of therapeutics.12th ed. Mc Graw-Hill. 2011:583-607.

6. Lowenstein DH. Seizures and epilepsy In: Longo, Fauci, Kasper, Hauser, Jameson, Loscalzo eds. Harrison's Principles of Internal Medicine 18th ed. Mc Graw-Hill; 2012:3251-3270. WHO-UMC causality assessment - Uppsala Monitoring Centre. Available at who-umc.org/Graphics/24734.pdf

7. Hasan SS, Bahari MB, Babar ZU, Ganesan V. Antiepileptic Drug Utilization and Seizure Outcome among Paediatric Patients in a Malaysian Public Hospital. Singapore Med J. 2010;51:21-7.

8. Ball DE, Taderera A. Development of Drug Use Indicators for Epilepsy. Cent Afr J Med. 2003:49(12):134-8.

9. Shah PA, Shapoo SF, Koul RK, Khan MA. Prevalence of Epilepsy in School-going Children (618 Years) in Kashmir Valley of North-west India. J Indian Med Assoc. 2009;107(4):216-8.

10. Udani VP, Dharnidharkari V, Nair A, Oka M. Difficult to control epilepsy in childhood-a long term study of 123 cases. Indian Pediatr. 1993;30:1199-206.

11. Porter RJ, Meldrum BS. In: Antiseizure drugs. Bertram G. Katzung, Susan B. Masters, Anthony J. Trevor eds Basic and clinical Pharmacology 12th ed. 2012;403-427.

12. Mc Auley JW, Lott RS. Seizure disorders. In: Mary Anne Koda-Kimble eds. Applied Therapeutics. The clinical use of drugs 9th ed. 2009;54:1-37. 
13. Conway JM, Kriel RL, Birnbaum AK. Antiepileptic drug therapy in children. In: Kenneth F. Swaiman, Stephen Ashwal, Donna M. Ferriero eds. Paediatric Neurology Principles and Practice. 4th ed. Mosby Elsevier. 2006:981-1005.

14. Arnold F, Parasuraman S, Arokiasamy P, Kothari M. Nutrition in India, in National Family Health Survey (NFHS-3) India. 2009. Available at http://www.rchiips.org/nfhs/nutrition_report_for_we bsite_18sep09.pdf. View at Google Scholar.

Cite this article as: Meenakshi B, Ezhil RJ, Ananthy Shri TRR. An analysis of prescription pattern and adverse drug reaction profile in children treated with antiepileptic drugs in a tertiary care teaching hospital. Int J Basic Clin Pharmacol 2016;5:389-93. 